\title{
Sustainability issues in agro-ecology: Socio-ecological perspective
}

\section{S. Kumaraswamy}

Department of Crop Physiology, University of Agricultural Sciences, GKVK Campus, Bangalore, India; kumar_cheers@hotmail.com

Received 13 December 2011; revised 18 January 2012; accepted 4 February 2012

\begin{abstract}
In the recent past there has been concern to address the declining trends and deteriorating ecological elements and their functions in productive agricultural landscapes. The efforts to revive the ecological functions needs multiple scale approach, which include scientific understanding, time dependent restorative activities and incorporation of wisdom of the stakeholders. Conservation initiatives linked to precision farming is an apt mechanism to minimize the loss of natural resources of agricultural landscapes to maintain the complex stabilizers of ecological functions. Such an effort must address the scientific evaluation of the farm as "ecologically sustainable unit" with due consideration to social construct at local to regional level. Sustainability indices can be useful tools for evaluating the farms to isolate degradative factors and identify ecologically conservative practices. This review will analyze certain inter-linked concepts relevant to address the sustainability issues in agro-ecology at the interface of socio-ecological perspective.
\end{abstract}

Keywords: Agro-Ecology; Biodiversity; Ecosystem Services; Conservation Farming; Sustainability; Social Capital; Climate Change

\section{INTRODUCTION}

Agro-ecology and its sustainability are revisited to apply ecological concepts and principles to restore the deteriorating productive landscapes. Revival of ecological farming at multiple scales at small farm level to larger scale in a landscape has direct implications for healthy agricultural practices to sustain the productive functions. Sustainability due to declining ecological functions and lack of social capital has caused damages to farmlands resulting in "hole in the doughnut" situation. Moreover, the contiguity of mosaic of farms and their connected aggravate the erosion of certain ecosystem functions of commonality. Such a situation can be a limitation while applying recouping concepts at smaller farms due the economic constraints and differences in their physical environment.

Recent past has seen increasing debate on participatory action research and its importance in agricultural sector get an insight on the qualitative and quantitative assessment of sustainability of agro-ecology [1]. It can be achieved through active participation of stakeholders at multiple scales, however as yet such studies have not been realizable due to complexity of issues and lack of social capital. Sustainability indicators have been used in natural science to analyze the health of farmlands. Despite the ubiquity of sustainability indicators [2], the comprehension and meaning by the communities at farm scale is still a constraint to apply PAR principles to visualize their ecological perspectives. It is suggested that the absence of community participation in the development of farm-level sustainability indicators is critical to maintain the integrity of regional scale agro-ecological functions [1,3]. Some researchers have adopted a comprehensive soil and vegetation based indicators for farm level assessment but lack socio-economic considerations [4]. Participatory mapping of the ecological health indicators in agricultural farms can facilitateidentification key ecological issues at regional scale [5]. Broad scale mapping of agricultural systems and likely impacting variables such as population pressure and climate change adversities using simple threshold as proxy for complex processes is yet another method to evaluate the sustainability of agro-ecology [6,7]. Such an analysis will be useful for identifying the dynamic hot-spots in agricultural landscape. It requires robust dataset on farm level to make comprehensive and meaningful impact assessments using sustainability indices.

Many of the environmental problems stem from modern agricultural activities and unaccountable perception of farming community. The current jeopardy is mainly attributed to green revolution and questionably it has caused catastrophic damage to the agro-ecological elements resulting in non-sustainability of farming practices. 
It is predicted that agricultural production will be doubled in 2050 calling for careful management of foot prints of agriculture [8]. It is indicative of the fact that it will increase further degradation of the agricultural systems and natural ecosystems with eventual decline in ecosystem services [9]. Projected doubling of agricultural activities must adapt sustainable practices and technologies as against the genetically engineered crops, which will minimize the pressure on land resources. Visibly, genetically engineered crops have been adapted by the farming community at large though skeptic views have been continually voiced by the environmental conservationists and ecologists [10]. Since the dawn of modern agriculture, the natural resources have been exploited leading to nonsustainability and degradation of agricultural landscapes [11]. The long term impact of degradative agricultural practices has emerged as major issue calling for agricultural policy reform.

Agricultural practices have evolved over the years to suggest that various farming practices are refined, researched and tested to analyze their feasibility as sustainable and economically viable on a long time scale. Further, majority of studies provide insight on the impact of range of cropping patterns and livelihood activities and how choices are shaped by their socio-economic and socio-political characteristics of the eco-region. Some of the studies have analyzed system evolution at multiple scales [12], factors determining technology adoption [13, 14], pathways out of poverty [15] and return to research investment [16]. Yet there appears need for discrete definition on farm level datasets and perspective plan to develop unifying framework for collecting information in standard format from a landscape scale. Farm level studies best suited to understand the practices at micro-level with implications for sustainability analysis of agro-ecology.

Numerous conservative schemes are designed to mitigate the impact of unsustainable agriculture and increase the value of the landscape in terms of sustained functions. Application of conservation concepts can be well matched with the precision farming so that spatially deficient resources are managed judiciously. Precision farming is difficult to practice due to smaller size of the farm and highly dispersed in fragmented landscape, which is critical limitation in conservative agricultural practices. The assessment of agricultural farming practices affecting the ecosystem services through their impact on biodiversity need a systematic analysis at farm to landscape scale. The mosaic of ecosystem services in ecological and conventional farming systems at farm level is presented in Table 1.

\section{AGRO-BIODIVERSITY: PROBLEMS AND SOLUTIONS}

Worldwide, agro-biodiversity erosion has been de- bated in various conventions linking to unsustainable use, degradative management practices, monoculture of high yielding varieties, intensive management inputs, markets forces, exploitation of land resources, habitat fragmentation and changing behavior of stakeholders $[17,18]$. It is stated that even the use of best technologies cannot prevent many of the forecasted problems. In this line a strategic planning of agricultural development is a need so as to preserve the agricultural biodiversity hotspots with minimal fragmentation and maximize range of ecosystem services. Currently farm level maintenance of ecological functions is considered as critical. Precision farming environments will help manage few soil based services viz., soil organic matter, enhance nutrient pools, beneficial microbial communities to optimize the soil ecosystem services. The in-situ biodiversity conservation at farm level as set asides through buffer habitat management would maintain naturally occurring and evolving populations of agriculturally useful species within their natural environment. Innovative approaches like biobanking [19] as adaptive participatory approach at farm and/or community level needed for in-situ conservation. In this direction institutional role is greatest to achieve the capacity building of the community at farm level for co-evolution and induce the network reciprocity to enhance the conservation attitude [20].

Biodiversity and ecological functions are inextricably linked to economic, cultural and social aspects of the stakeholders. Biodiversity spread across the ecosystem is unique and its integrity is governed by the interactions with the immediate exploitative elements of the system. Agro-biodiversity is one such portion has vital linkages to the socio-economic stability of the region. Agro-biodiversity has been under various scales of studies to address the issues related to fast disappearance of the economic traditional varieties/wild relatives/land races [21]. Agro-ecology presents complex of issues in this direction due to shifting paradigms and major dependency on modern agricultural practices resulting in progressive loss of genetic resources, land degradation and erosion of belowground biodiversity. Further, it aggravates the vulnerability of agricultural production systems to pest and disease risks, environmental stability eventually contributing for declining food security. Thus, conservation and sustainable utilization of the agro-biodiversity at local to regional scale has become agenda for discussion at national to international level.

Biobanking can be an appropriate in-situ conservation mechanism that assists in conserving one or more diverse populations of species in a site. Farm level approach in a landscape will provide an ideal situation to address the conservation of genetic resource pools of micro- and macro-scale. The sites selected for biobanking process must have specific evolutionary processes hence serving 
Table 1. Mosaic of ecosystem services basis in ecological and conventional farming systems at farm level.

\begin{tabular}{|c|c|c|}
\hline $\begin{array}{c}\text { Indicators/ } \\
\text { Services/Functions }\end{array}$ & Ecological farming & Conventional farming \\
\hline Soil health-Physical & Best for most crops & Poor to moderate depends on farming practices \\
\hline Structure & Stable, suitable for most cropping pattern & Poor, destruction of crumb structure \\
\hline WHC and infiltration & High, minimal run-off, high infiltration rates & Poor, depends on the practices \\
\hline $\begin{array}{l}\text { Nutrient stores/Nutrient } \\
\text { cycling }\end{array}$ & $\begin{array}{l}\text { Good, slow release, demand based supply, closed } \\
\text { nutrient cycling, on-farm organic residues recycling, farmers } \\
\text { intuitive skills of evaluation of soil conditions }\end{array}$ & $\begin{array}{l}\text { Poor, eroding type, minimal nutrient } \\
\text { replenishment capacity, supplementing nutrients } \\
\text { through chemical fertilizers, high fossil fuel } \\
\text { based energy consumption }\end{array}$ \\
\hline \multicolumn{3}{|l|}{ Soil health-biological } \\
\hline Beneficial microbes & $\begin{array}{l}\text { High-cumulative effect, synergistic groups, controllable } \\
\text { through the inputs addition matching with cosmic beliefs }\end{array}$ & $\begin{array}{l}\text { Poor, loss of certain species, poor resilience of } \\
\text { microbial groups, }\end{array}$ \\
\hline Functional microbes & High—synergistic enhancement of required groups possible & Loss of functional groups \\
\hline $\begin{array}{l}\text { Water quality-Surface } \\
\text { water bodies }\end{array}$ & $\begin{array}{l}\text { No pollution, absorption of excess nutrients, minimal leaching } \\
\text { of nutrients to water bodies, high nutrient retention capacity, } \\
\text { lesser nutrient migration to water bodies, matching the nutrient } \\
\text { demand with requirement }\end{array}$ & High loading of nutrients \\
\hline Groundwater & No or minimal effect—nitrate leaching & High—nitrate, phosphorus, pesticide loading \\
\hline \multicolumn{3}{|l|}{ Carbon sequestration } \\
\hline Physical & $\begin{array}{l}\text { High, provides option to diversify vegetation types-include } \\
\text { perennials, reserve carbon in aboveground biomass, carbon } \\
\text { credits, }\end{array}$ & Poor, depleting type \\
\hline Microbial biomass & High & Poor \\
\hline Greenhouse gases flux & $\begin{array}{l}\text { Low, circumstantial releases depends on management practices } \\
\text { Controllable }\end{array}$ & $\begin{array}{l}\text { High, faster depletion of } \mathrm{C} \text { from soils, accelerate } \\
\text { the greenhouse gases emission and type depends } \\
\text { on the management practices }\end{array}$ \\
\hline $\begin{array}{l}\text { Biodiversity value- } \\
\text { Aboveground }\end{array}$ & $\begin{array}{l}\text { Depends on the agro-systems, generally enhances the } \\
\text { biodiversity } \\
\text { Selective enhancement of biodiversity is possible, high } \\
\text { functional diversity—pollinators, predators, biological } \\
\text { pest/disease control agents }\end{array}$ & $\begin{array}{l}\text { Low biodiversity, selective loss of species, mono } \\
\text { species, loss of functional diversity, invasive } \\
\text { species of high economic damage to crops and } \\
\text { environment }\end{array}$ \\
\hline Belowground & Functional diversity is high, synergistic microbial groups & Low, poor recouping capacity \\
\hline Quality of products & High, nutritive produce, seed quality, less genetic segregation & $\begin{array}{l}\text { Poor, high genetic segregation of hybrids, genetic } \\
\text { dilution of varieties due to cross pollination }\end{array}$ \\
\hline Aesthetic/cultural value & High & Poor \\
\hline Human health risk & $\begin{array}{l}\text { Low, weed control through crop rotation, biological and } \\
\text { organic pesticides used for pest control, no toxic residues, } \\
\text { high well-being satisfaction }\end{array}$ & $\begin{array}{l}\text { High, pesticide, herbicides residues, fertilizers, } \\
\text { growth enhancing chemicals }\end{array}$ \\
\hline Sustainability value & $\begin{array}{l}\text { High, stability due to diversification, ecological orientation, } \\
\text { responsive production to match the crop with site productivity }\end{array}$ & $\begin{array}{l}\text { Poor, economic orientation, mechanized, market } \\
\text { driven production practices }\end{array}$ \\
\hline Acceptability/Choices & $\begin{array}{l}\text { Slow in acceptance, selective educated farmer prefers organic } \\
\text { cultivation, low economic returns and less } \\
\text { productivity per unit area, crop diversification possible, } \\
\text { personal choice }\end{array}$ & $\begin{array}{l}\text { High, marginal economic returns at the cost of the } \\
\text { sustainability elements of the land, air and water }\end{array}$ \\
\hline $\begin{array}{l}\text { Socio-economic capital } \\
\text { and human dimensions }\end{array}$ & $\begin{array}{l}\text { Holistic approach, mixed production and private } \\
\text { economy, transparent consumer attitudes on nutritional quality, } \\
\text { no pollution, conservation of soils and } \\
\text { ecological elements, accretion of soil ecological } \\
\text { services, culturally dependency of farming activities vary from } \\
\text { farm to farm, evolving innovative green technologies }\end{array}$ & $\begin{array}{l}\text { Poor, blind followers, market driven knowledge, } \\
\text { poor technical skills, erosion of ecosystem } \\
\text { services, high risk economy, high pollution at farm } \\
\text { level, poor consumer relationship, loss of inherent } \\
\text { functions of soils, land degradation, mechanized } \\
\text { and high cost }\end{array}$ \\
\hline Agro-ecotourism & High, educative and evolving research sites & Poor, high cost for restorative research \\
\hline $\begin{array}{l}\text { Vulnerability to } \\
\text { climate change }\end{array}$ & $\begin{array}{l}\text { Minimal, crop diversification and traditional adaptive } \\
\text { technologies }\end{array}$ & High, crop failures, pest and disease outbreak \\
\hline
\end{tabular}


as on open laboratory permitting continued evolution and conservation of the component species. The size of the conservation site in a landscape is determined by elements like 1) current threats to natural resources, genetic variants and nature of threats; 2) how does species reproduce (wind, insects, birds etc.); and 3) ability of select species to maintain its biological sustainability. Farm specific indigenous knowledge and criteria for conservation need to be integrated in biobanking process as participatory approach.

Currently, there is need for effective implementation of policy framework addressing economic incentives for conservation of agro-biodiversity [22]. Current system of subsidies on various agricultural inputs to enhance the agricultural productivity has been a drawback as it accelerate the depletion of inherent ecosystem services of farm. It complicates the proposition of dual objective of increased productivity and conservation of ecosystem services. However, a precise incentive scheme, which is suitable to expand biological and agronomic practices that is specific to agro-systems and regions will help make right decision at the farm level in terms of inputs use efficiency and resource protection. It calls for designing a suitable framework at farm scale to develop conservation agricultural activities. It requires substantial knowledge on technologies, robust database on farm matrices and their interactive state in a landscape for precise decision-making process. Moreover, it requires application of sustainability indices [23-28] to identify the farm, which comply with the conservation activities. It is useful to rationalize the farm scale analysis of agrobiodiversity with broader aim to analyze data to identify hot spots of agro-biodiversity, habitat fragmentation implications and develop adaptive community based participatory conservation activities specific to cluster farms and/or specific farm.

Sustainable agricultural practices must address the conservation of biodiversity, improved ecological functions, social acceptability, self-reliance, equity, improved quality of life and economic productivity of crops and livestock. Sustainability of agriculture is viewed critically from the point of food and ecological security at the regional scale. Conceptually, effective sustainable agriculture practices must be analyzed through three basic elements; 1) maintenance of environmental quality; 2) synergistic interaction of plant and animal productivity; and 3) social acceptability with economic benefits. It is suggestive that agricultural sustainability should be addressed from the perspective of maintenance of ecological integrity, social acceptability and economic viability [29]. These factors in their interactive state in farm level provide critical insight on the indicators and conservation prospects. A common framework like driving force-state response (DSR) developed by OECD [2] uses changes to farm management practices and input use. It identifies 39 indicators viz., financial resources, farm management, nutrient use, pesticide use, water use, soil quality, water quality, land conservation, greenhouse gases, biodiversity, landscape, wildlife habitats and farms contextual information, socio-economics, land use and output. Large numbers of indicator based analysis have been done at various scales but each one has inherent limitations suggesting construction of farm specific analysis within the context of contemporary socio-economic situation [30]. Plausibly, holistic analysis of agro-ecology at microscale calls attention to analyze the agricultural practices that alter the ecosystems functions through their impact on agro-biodiversity.

\section{SUSTAINABLE AGRICULTURE: SCALE OF INDICES}

Sustainable agriculture is distinct from the point of resource use, nature of inputs, cropping pattern, degree of diversity, cultural practices, methods of plant protection, management of resources and degree of dependency on local external resources and knowledge [31,32]. The concept of sustainability has been debated in response to concerns about the adverse environmental and economic impacts of conventional agriculture [33], excessive imbalanced use of agro-chemicals, dependence on external inputs, use of fossil fuel energy, decline in soil productivity, increasing land degradation at landscape scale, contamination of surface and groundwater, adverse effects on human and animal health [34-36]. The cost of environmental impacts of modern agricultural practices typically unmeasured and often do not influence the farmer or societal choices about the production practices. On the contrary, sustainable agriculture is viewed as regenerative, makes efficient use of on-farm resources, effectively uses local knowledge, conservatively uses skills of farmers to improve their self-reliance and capacities and minimally uses the external and nonrenewable inputs to the extent that these are deficient in the natural environment [37]. Many views have been expressed by the researchers on the sustainable agriculture, which range from low use of external inputs [38,39], enhancing production [12], minimal use of external inputs to maintain the nutrient levels [40], proactive concern to maintain the ecological health and sustainability [40-42], biodiversity enhancement $[43,44]$, landscape quality $[45,46]$, integrated nutrient management [47] as prerequisites for conservative yet economic agricultural production practices. Likewise, organic agriculture is synonymously used with sustainable agriculture due to its positive change on ecological health. Some argue that non use of inorganic chemicals does not qualify as sustainable agriculture [47]. It further raises concern on the economic 
sustainability in terms of net present value, benefit-cost ratio and profitability. The recent past has seen increased attention paid to "social capital" to address the adaptive acceptance, which contribute for the agricultural sustainability through co-evolution and network reciprocity $[48,49]$.

Sustainability also viewed as "social construct" due to its site-specificity and dynamisms [50,51]. Community bears strong control on improving the biological diversity, stability and resilience of the land use systems through site specific management of crops. Some studies have used yield and productivity of land as indicators of sustainable practices [52]. Similarly, maintenance of productivity, reduced risk, natural resources conservation, promotion of economic viability and social acceptability are suggested to be the scale in sustainable land management [26]. A number of sustainability analyses use various indices, which appear to have site-specificity. On the constrary, generic indices to suite the landscape scale analysis is not feasible as individual farm differ in terms of the decision on technologies to be used in land use practices [47]. Several indices are currently used to analyze the sustainability practices at farm level. For instance, capital asset value in terms of money and energy use in two farms has been used to analyze the sustainability [53]. Likewise, integrated nutrient, water and pest management, in-put self sufficiency, self-reliance, crop security and family food sufficiency have been used while analyzing rice production systems [54]. More precisely, ecological (nutrients, organic inputs, water, energy, environmental impacts), economic (farmer's livelihood systems, cost of inputs, food security) and social construct criteria (competition, traditional knowledgebase, employment options) more suited for the analysis of agricultural sustainability [55].

Current interest of landscape scale analysis will through light on impact of ecosystem fragmentation on the ecosystems services solely endemic to agricultural activities. The analytical consideration has to be "farm as miniature biome and their connectedness", which is experiencing increasing unsustainable practices leading to loss of ecosystem services from agricultural landscapes. Furthermore, modern agriculture has lead to decline in recouping of the land resources and selective loss of biodiversity. Farming community is caught unawares and scientific analysis of farm level data suggests that the recouping capacity of agro-ecology in terms of land productivity and associated biodiversity is threatened. Soil ecosystem services in terms of recouping capacity of beneficial microbial groups, nutrient buffering capacity and stability of productive capacity has declined at alarming rates, which is speculated to be site specific and influenced by the management practices. Considering the adverse effect of the conventional farming activity, con- servative practices complemented by precision farming in line with the Fukoukas natural farming [56], principles have evolved as alternatives to bring in the element of sustainability. However, the acceptance of the promising practices at farm level has faced many limitations due to crop failure risks, economic viability and extended time required to convert the conventional to self sustained farm.

The restoration of degraded and/or progressively degrading farm systems is complex and theoretically deemed difficult in situation of exploitative management practices for economic benefits of miss calculations [57]. The concept of a farm level approach does not mean selfcontained set of adjacent farms near the household, but a mosaic of interactive farms at different distances with in a landscape. Landscape scale approach allows analyzing substantial flexibility in capturing the complex land-use systems, transactions (knowledge base, labour, nutrients dynamics) between farms, crop management practices and product use by smaller farms. Further, it facilitate the analysis on loss of natural capital in agricultural landscapes, disappearance of prey-predator relationship and decreasing carbon stocks in soils [58-60]. Essentially, sustainable agricultural activities mean reconciliation between biodiversity conservation and increased agricultural production [61]. Sustainability indicators are ambiguously used by many researchers unlike the views of farming community. The indicators can be alternative measures to identify the status of concern in the absence of technical or financial constraints, which cannot be measured directly [62]. Likewise, the challenge is the problem of aggregation of ecological, social and economic indicators, which are incommensurable to arrive at overall assessment of farms [63]. Further, non-material dimension of sustainability as culture and social identity complicate the analysis in generic term [28]. As many as 12 indices (Table 2) have been suggested for various situations to analyze the sustainability of agriculture practices keeping in mind farmers and policy makers at regional, national and global levels [2,31,64-66]. However, definition of sustainability indicators at farm level cannot be on relative terms as farm to farm activities differ greatly in a landscape. Reviews on the sustainability indicators [67] corroborate the challenges of disciplinary and methodological heterogeneity, with cross cutting environmental and social sciences, which induce dissimilarity in sustainability variables. Additional indices, which address some of the critical aspects of agroecological health and vulnerability to disasters, need attention (Table 2). They include; 1) Environment Vulnerability Index (EVI): It is natural disaster threats to farming activity aggravated by the anthropogenic degradative factors. EVI use vulnerability definition in terms of degree of resilience to various hazards/damaging 


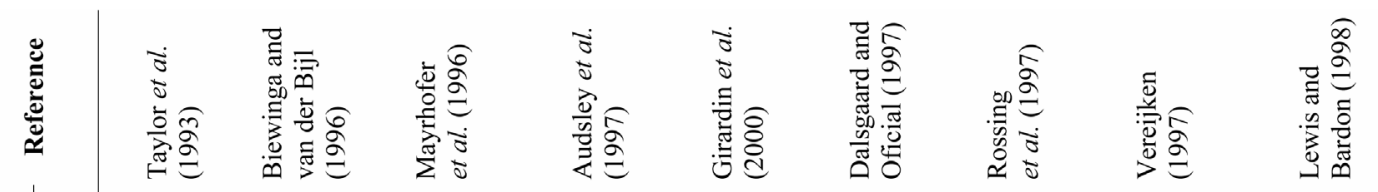

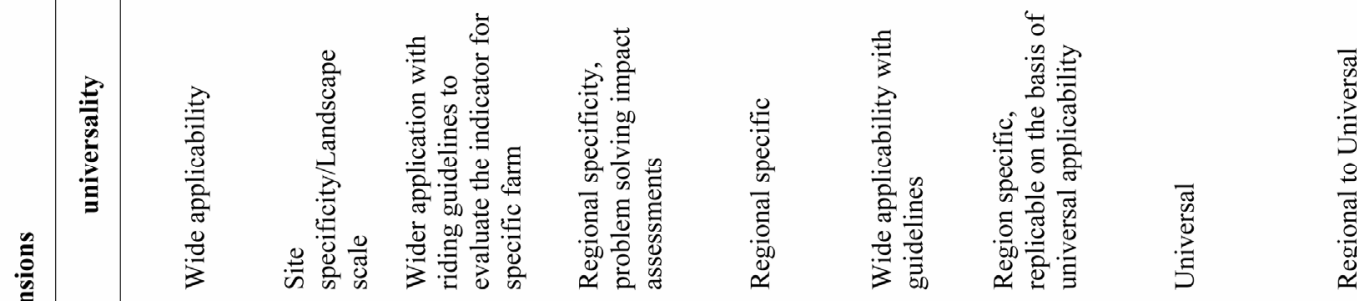

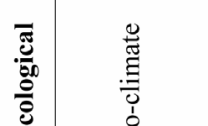

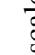

Is

高部

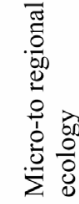

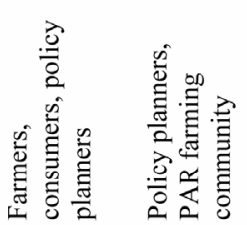

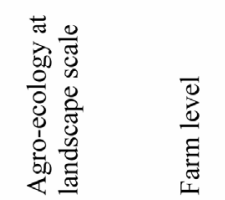

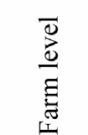

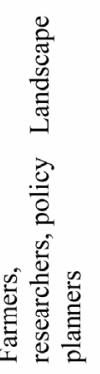

苛

告

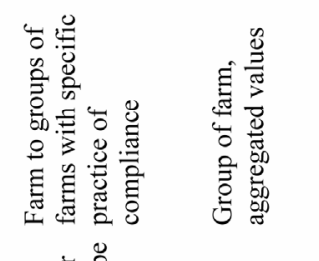

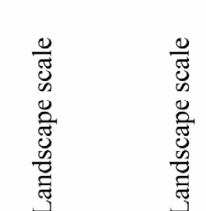

究

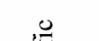

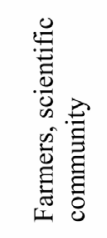

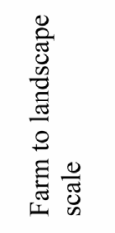

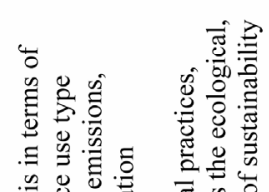

葶

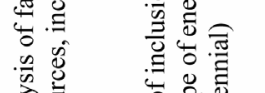

sil

in

旁高

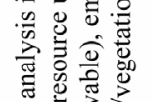

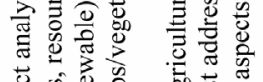

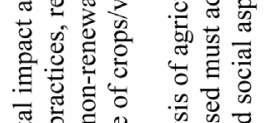

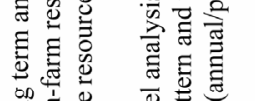

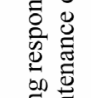

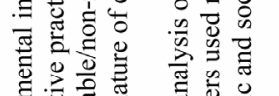

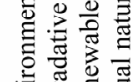

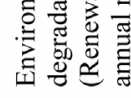

In

है

志

志

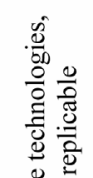

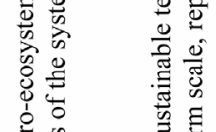

空.

焉最

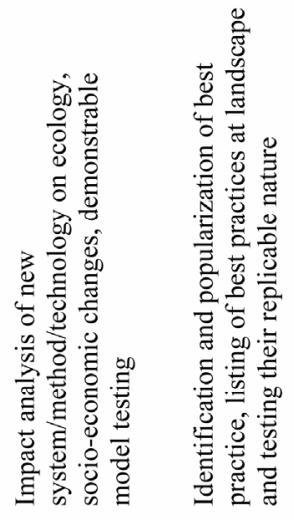

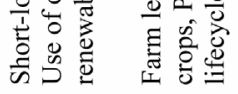

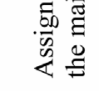

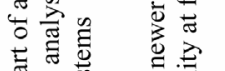

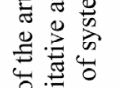

.

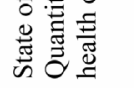

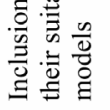

.
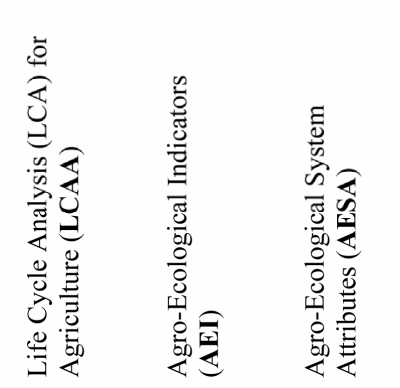

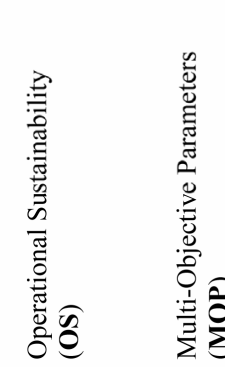

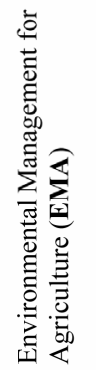




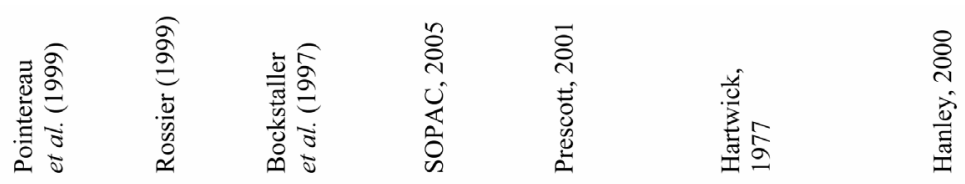

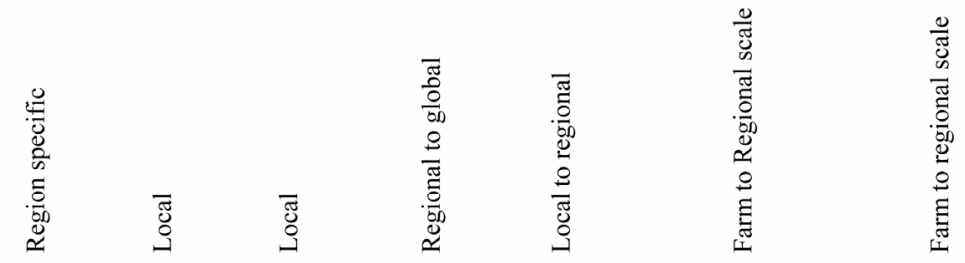

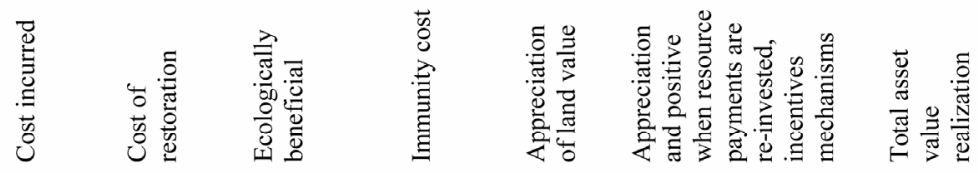

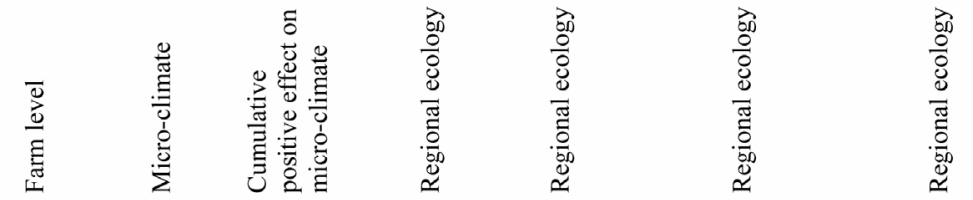

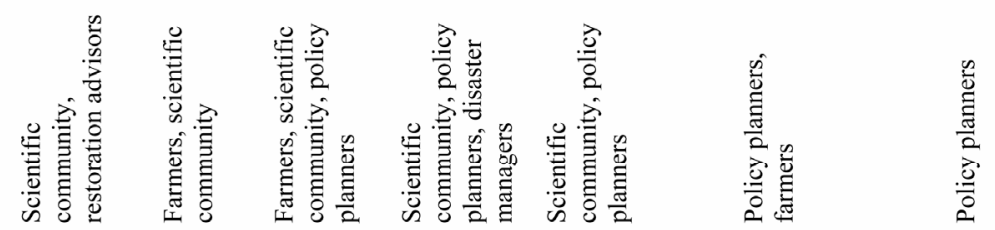

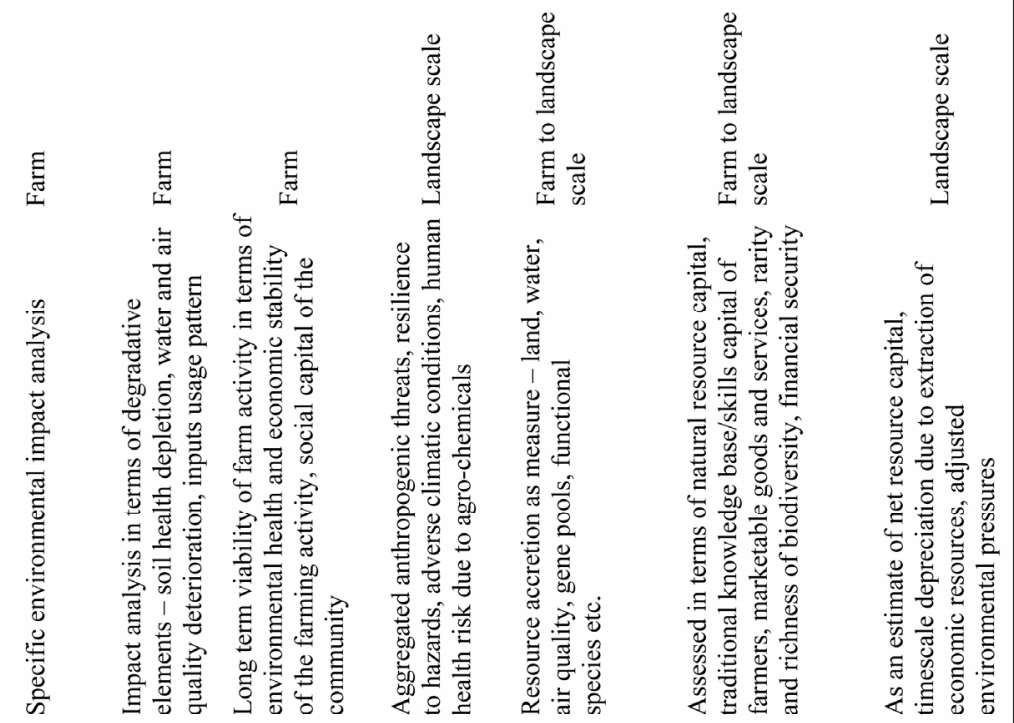

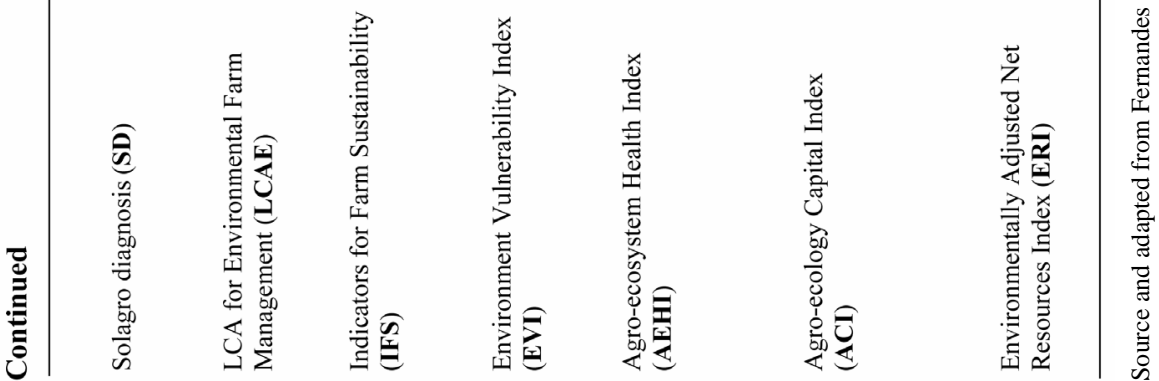


indicators [65]. The indicators may be identified at local, regional and/or global scale (For instance, effect of climate change on species loss). Pooled weights will provide insight on the vulnerability and suggest measures to enhance resilient mechanisms both for natural and man-made hazards (For instance, industrialization and population pressure); 2) Agro-ecosystem Health Index (AEHI): It includes the evaluation of the land resources, water resources, air quality, functional species richness and gene pools in an agricultural landscape [68]; 3) Agro-ecology Capital Index (ACI): It can include the natural resource capital, traditional knowledge/skills capital at farm level, marketable goods/services capital. In this case, the total asset capital linked to biobanking process may be assumed positive when the resource payments are re-invested to ensure that capital stock will never decline [69]. It can include certain incentive mechanism to bring in required positive change in conservation of agro-biodiversity. It must consider the asset value in terms of uniqueness of functional richness of diversity, rarity, traditional varieties and threatened species conservation efforts across the farms enabling better contested ranking to assign incentives [70]. However, it must have internalized EVI to assess the resilience factor; iv) Environmentally adjusted net Resources Index (ERI): Similar to System of Integrated Environmental and Economic Accounting [71,72], must consider all natural resources to assess the net resource capital (biodiversity; functional vs species richness) depreciation due to extraction of economic resources and subtraction of the adjusted environmental pressures and destruction forces.

Ecological indicators are useful to understand the magnitude of change, amount of exposure to change or degree of response to the exposure [73]. Scientific methods defining comparability, weighting and aggregation are pre-requisites for construction of meaningful sustainability indices. Generic models, which facilitate data inputting and sharing across the disciplines, serve the scientific community to integrate the analyses across the locations [30]. In most of the cases, model based outputs will have limitations when analyzed at the scale of effects-means, where as one can conceive an experimental approach to validate the effect-means based indicators, which are inherently subjective. Currently used sustainability indices in terms of means and effects appear to be arbitrary and lack robust scientific basis to arrive at threshold values [74]. However, the threshold values are not acceptable because of interactive nature of physical and biological factors [63]. It is opined that large efforts in the last decade have failed to identify widely applicable single index [75]. Some argue that good indicators should be user derived as well as policy relevant and highly aggregated [76]. However, aggregation methods do not facilitate decision-making due to the ambiguity of single index arising out of various dimensions of sustainability. definitive indicators with defined objective and absolute comparable values act as useful tool in construction and operationalization at farm level sustainability analysis. Certain criterion and indicators applicable for establishing the sustainability indicators at farm level are presented in Table 3.

Applicability of sustainability principles to landscape scale has significant potential for buffering the off-site consequences of agriculture at regional, watershed and farm level to take advantage of services provided by contiguous natural, semi-natural and restored ecosystems. These contiguous systems provide suitable habitat for pollinators, predators and parasites contributing for better productivity of cropland in a landscape. Thus, landscape approach must consider overall maintenance of ecosystem services provided by agro-ecology, which can be evaluated on the scale of sustainability indices. Although many indicator-based sustainability monitoring tools have been developed in the last decade but considerably less effort has been made to validate their applicability [77].

\section{LINKING AGRO-ECOLOGICAL DEVELOPMENT WITH PARTICIPATORY ACTION RESEARCH}

Last decade has seen increasing need to address the agricultural developmental issues from the perspective that incorporates social and ecological dimensions. Participatory action research (PAR) holds the key and has relevance to raise the queries on the intuitive wisdom of stakeholders on sustainable agro-ecological practices [78]. PAR is an adaptive social research through the integration of scientific basis to improve the overall management approach by the stakeholders. Unlike the extension activities, the close interactions in PAR promote broad participation in the research process and supports action leading to satisfying situation. Moreover, it reliably addresses the integral question of linking the ecological conservation initiatives as part of the socio-economic development at local scale. It raises queries on gains and losses in terms of maintenance of water quality, biodiversity, carbon storage, pest control, pollinators and predators, fisheries and ecotourism in agricultural landscapes. Thus future revolution agricultural productivity must work on the principles of PAR that incorporates accumulated knowledge of ecological processes and feedbacks, disease dynamics, soil processes and beneficial microbial functions [8,78]. A cyclical approach of PAR is promising in situation, which involves diversity of active stakeholders in research and as agents of positive change. The cyclic process of PAR includes observational, reflective thinking, experimental actions and co- 
Table 3. Criterion and indicators used for establishing the sustainability indicators at farm to landscape scale.

\begin{tabular}{|c|c|c|c|c|}
\hline \multirow{2}{*}{$\begin{array}{l}\text { Elements of } \\
\text { sustainability }\end{array}$} & \multirow{2}{*}{ Measurable parameter } & \multirow{2}{*}{ Usage of indices* } & \multicolumn{2}{|c|}{ Applicability } \\
\hline & & & Scale & Dimension \\
\hline Land & Farm size/small land holdings frequency in a landscape & ACI, ERI & Regional & $\begin{array}{l}\text { Landscape } \\
\text { ecology }\end{array}$ \\
\hline Soil & $\begin{array}{l}\text { Physical and biological fertility index parameters-OM, Major } \\
\text { and micronutrients dynamics, Soil type, Texture, Structure, } \\
\text { WHC, amenable for organic farming practices, nutrient removal } \\
\text { pattern in plant biomass and grains, farmers perception of soil } \\
\text { quality }\end{array}$ & $\begin{array}{l}\text { FSI, AEI, EP, } \\
\text { LCAE, LCA }\end{array}$ & Farm & Landscape ecology \\
\hline Water & $\begin{array}{l}\text { Availability for drinking and irrigation purpose, quality, salinity, } \\
\text { history of scarcity, water usage pattern for irrigation — surface } \\
\text { or micro-irrigation }\end{array}$ & FSI, LCAE & Farm/Regional & $\begin{array}{l}\text { Watershed/Depth } \\
\text { of water table }\end{array}$ \\
\hline Biodiversity & $\begin{array}{l}\text { Traditional varieties, land races, wild relatives, rare and } \\
\text { threatened species, genetically modified crop varieties, crop } \\
\text { diversity, mixed cropping, gene pools, landscape scale genetic } \\
\text { diversity, livestock—-traditional breeds }\end{array}$ & ACI, AHI, EP & Farm/Regional & $\begin{array}{l}\text { Landscape } \\
\text { diversity pool }\end{array}$ \\
\hline Energy balance & $\begin{array}{l}\text { Use of fossil fuel, } \mathrm{N} \text { fertilizers, renewable energy source, share } \\
\text { of renewable inputs (ex. Bio-fertilizers etc.) }\end{array}$ & LCAA, AEI, SEC & Farm/Local & Landscape ecology \\
\hline Human Health & $\begin{array}{l}\text { Diseases out-break, health risk associated with pesticide usage, } \\
\text { history of health of farm family, loss of work force due to } \\
\text { chronic disease, pesticide hazard index, composition of toxic } \\
\text { pesticides, health index }\end{array}$ & FSI, EVI, SD & Farm/Local & Landscape ecology \\
\hline $\begin{array}{l}\text { Social } \\
\text { Capital/Political } \\
\text { representation }\end{array}$ & $\begin{array}{l}\text { Farmers schooling level, education index, participation of } \\
\text { farmers in extension service, community organizations and } \\
\text { contact with research-developmental institute at regional scale, } \\
\text { knowledge market, historical knowledge of agriculture, farm } \\
\text { family perception on well-being, perspective continuity of } \\
\text { farming business, power to influence agricultural councils }\end{array}$ & AEHI, FSI, OS & $\begin{array}{l}\text { Farm/Local/Regio } \\
\text { nal }\end{array}$ & Society \\
\hline $\begin{array}{l}\text { Infrastructure and } \\
\text { financial stability }\end{array}$ & $\begin{array}{l}\text { Roads, electricity, farm buildings, dependency on farm } \\
\text { machinery, tractor, bullock carts, on-farm and non-farm income, } \\
\text { family living expenditures, farm produce demand price, } \\
\text { input/output price ratio }\end{array}$ & MOP, ACI & Farm & Economy \\
\hline Food security & $\begin{array}{l}\text { Sufficiency of farm produce of food items, raw materials, } \\
\text { surplus for lean period, high value crop produce, on farm } \\
\text { sufficiency, barter exchange of farm produce, organic farm } \\
\text { produce, type of produce, quantity }\end{array}$ & $\begin{array}{l}\text { IFS, OS, EMA, } \\
\text { FSI, }\end{array}$ & $\begin{array}{l}\text { Farm/Local/Regio } \\
\text { nal }\end{array}$ & Economy \\
\hline $\begin{array}{l}\text { Health of } \\
\text { agro-ecology }\end{array}$ & $\begin{array}{l}\text { Overall health of farm, soil health, productivity, crop } \\
\text { diversification, use of natural resources, rural economy from } \\
\text { agriculture, biodiversity value, integrity of contiguous } \\
\text { ecosystems }\end{array}$ & $\begin{array}{l}\text { AEI, AESA, AEHI, } \\
\text { EVI }\end{array}$ & Regional & $\begin{array}{l}\text { Ecology and } \\
\text { Economy }\end{array}$ \\
\hline
\end{tabular}

*Refer Table 2 for sustainability indices explanation; Adapted from Fernandes and Woodhouse, 2008.

evolution through network reciprocity $[23,79]$.

The duality of the PAR is important to create positive social and environmental change contributing essentially to scientific knowledge gain to stakeholders. It facilitates strategic and potential expansion of PAR linkages among the communities, organizations, researchers and development of network for mutual learning. However, longterm sustenance of the PAR cycle is challenge by itself due to changing priorities of the stakeholders and researchers. It is one of the drawbacks which may add skeptic view to PAR oriented approach to agro-ecological development initiatives. Many options may be created by asking questions in the initiation stage of the
PAR process to make the PAR activity adaptable. The relevant questions may range from level of participation, powers of participants, gender issues, caste discriminations, social roles of participants within the communities, social skills of scientific researchers and interactive forces operating at spatial, geographic and political scales $[25,80]$. In PAR approach, much importance need to be paid to benefit the adaptive management strategies (active and/or passive) in natural resource management [81-83].

PAR provides an option to understand the degree of participation in research and change process. The typology and the degree of relationship has been suggested 
[84] based on participation at the level of 1) Collegialtrust based relationship where researchers work in close association with local stakeholders to strengthen their research, developmental capacities and practice advocacy; 2) Collaborative-a direct collaboration between researchers and stakeholder with realizable objective/s; 3) Consultative-researcher orients his approach to need based solving of problem of the stakeholder/s; and 4) Contractual-service oriented contract between the researcher and stakeholder [85]. All these relationships can be operational at one time, however need empowerment of local communities of their social capital aiming at positive change as a long and negotiated process [84]. The uneven power relationships, conflicts, rivalry, multiple cultures, caste based discrepancies operate while building PAR for agro-ecological sustainability.

\section{ENVIRONMENTAL SOCIOLOGY PERSPECTIVE}

Environmental sociology is increasingly becoming indispensable in restoration of ecological functions. By definition environmental sociology is "complex symbolic and non-symbolic reciprocal interactions between society and environment, which are influenced by the cultural and social behavior while interacting with the physical and biological elements" [86,87]. Agricultural landscapes provide ideal systems for environmental perspective analysis of development as human-well being holds the key to sustainability. Agricultural extension is recognized approach for lab-to-land dissemination of research output to farming communities. It fails to consider farm level innovations, which have not been documented but practiced in isolation. In such situation, PAR is best suited to operate in both direction with extension and learning the lessons from traditional experimental farming by the stakeholders. In this view, experts and farmers are guided by a knowledge interest in "technical power of control over an environment" and perceive their participation in environment as a sphere of instrumental rationality. Accordingly the farmers will have habitualized the laws of environment as behavioral rules. Indeed, co-evolution and network reciprocity of the farmers must be characterized as all human knowledge of environment is inevitably tied to the interest in ecological sustenance. Hence, environmental sociology perspective at farm level could be used to reconstruct the theoretical basis for sustainable development of agricultural landscapes.

There is need for paradigm shift in extension activities and PAR to analyze the current situation and circumstantial changes to agricultural landscapes. Thus far the principles of extension have been aimed at increasing the productivity, which theoretically might negatively impact the sustainability of agricultural landscapes. PAR princi- ples provide a basis for such an approach in the current theory of establishment of farm level sustainability and economic viability of production systems. Thus the meaning of sustainability assumes conservation and capacitating the farming communities through PAR to maintain the ecological services to achieve the new paradigm shift in productive agricultural landscapes.

The concept of sustainability and economic rationality seem become inseparable and having their own legitimacy in agricultural landscapes. The inter-linked matrix of operative factors contributing for the integrity of agroecology is indicated in Figure 1. Development in agricultural landscapes is becoming more pluralistic as policy planners, farmers, environmentalists, conservationists and consumers have variable perceptions on the sustainability. These perceptions and priorities range from ecological, agro-technological and socio-economic dimensions. Thus, increasing the limits of acceptability of sustainability indices in agro-ecology must assume constructive terms, which defines collective participation, compromise, learning (intergenerational), conflict resolution and sustained interactions [88]. The sustainability model based on the theory must seek a dialectical union of development and environment [89]. The emerging concepts highlight the importance of joint learning, coevolution and network reciprocity [90]. Arguably, sustainable agricultural process such as co-evolution and negotiation to bring in the element of sustainability cannot be achieved without strong leadership at local level.

\section{AGRO-ECOLOGY AND CLIMATE CHANGE: CONTROLS AND ALLEVIATION MEASURES}

Global environmental change has the potential to exacerbate the ecological and societal impacts on agrobiodiversity [91]. In many regions, land conversion forces declining populations towards the edges of their species range, where they become increasingly vulnerable to collapse if exposed to further human impact and climate change [92]. The combination of irreversible species loss and positive feedbacks between biodiversity changes and ecosystem processes are likely to cause nonlinear cost increases to society in the future, particularly when thresholds of ecosystem resilience exceeds [93]. Climate change presents yet another challenge of increased habitat alterations affecting both food and nonfood crops composition at landscape to regional scale. Agro-ecological system is already in the mode of rapid change leading to species range shifts and changes in plant diversity leading to lesser indigenous traditional plant species [94]. Further, the impact of climate change will have differential effects on the species through the adversities of deficient hydrological regimes, high tem- 


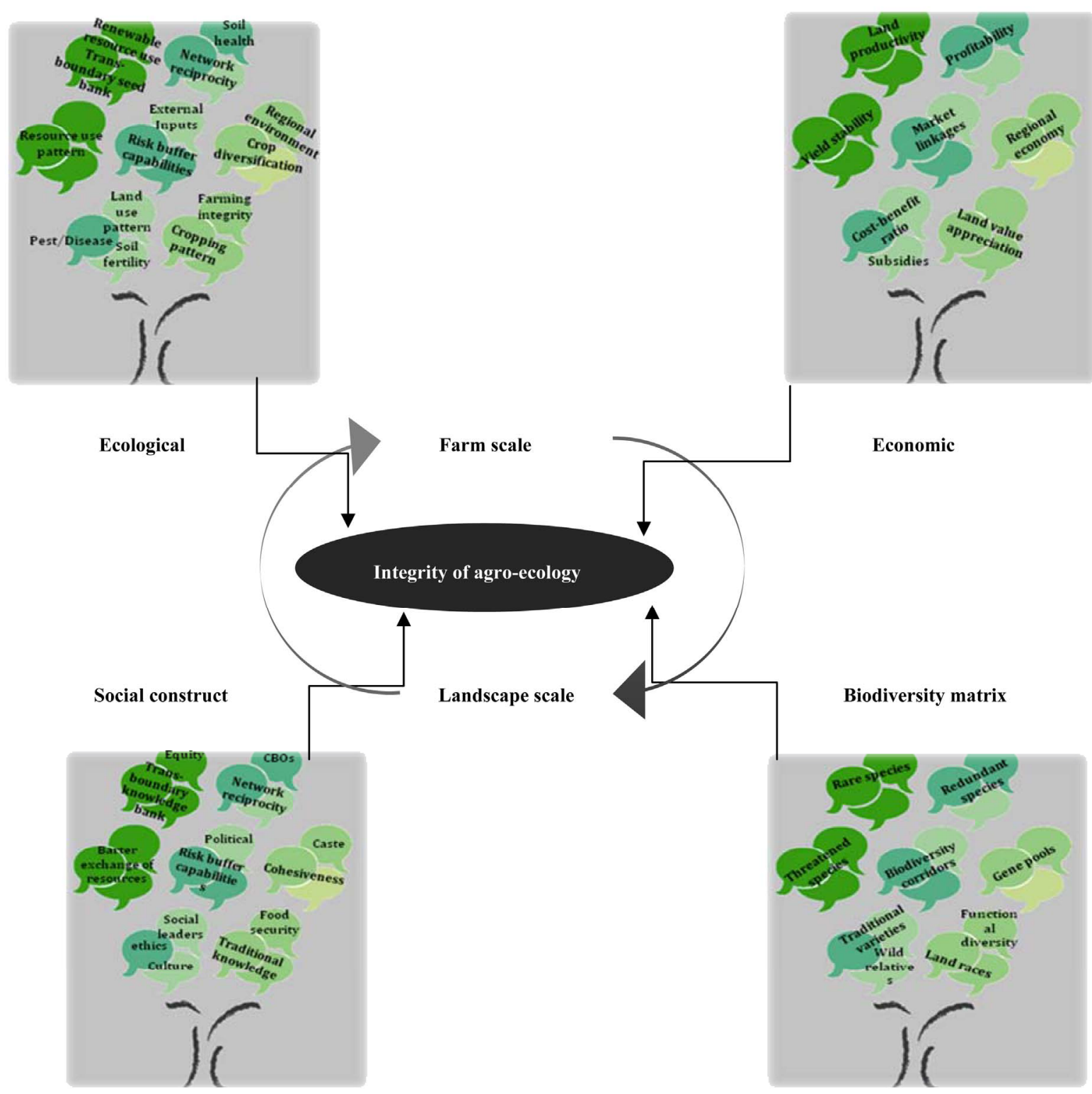

Figure 1. Trees with indicators and impacting factors in agricultural landscapes.

perature, and variation in length of growing season and increased frequency of extreme weather [95].

The changing climatic conditions may bring about few environmental benefits in some region. However, the preparedness requires evolving adaptive strategies to change the cropping patterns, change the farm operation timing, use of traditional crop varieties, improve water use efficiency, improve soil fertility, flexible institutional and governmental policies to suite diverse farming systems [96]. Likewise, agro-biodiversity hotspots must receive increased attention to conserve and safeguard the species of local origin $[97,98]$. Thus, the preparedness for the projected climate change requires building social capital at farm level. Further social capital building must be directed to understand the use of traditional varieties at farm level to landscape scale, species composition of contiguous/fragmented ecosystems, biodiversity value and spread of ecosystem services (pollination, predation and source of genetic materials), degree of resilience of farms and identify potential alternative livelihood support systems. Most of the traditional farming systems and practices may exhibit high resilience to the impact of climate change. Modern agriculture systems are categorized as destructive to ecosystem services due to intensive management practices. Further, agricultural systems may reach the point of collapse under climate change scenarios where the conventional agriculture has eroded much of species diversity of the buffer ecosystems and their services.

There is need for integrating multiple scale analysis to 
include variability of current and projected climate, seasonal change impacts, risk proofing mechanisms, alternate land use plans to understand the vulnerability and sustenance of farm productivity (Table 4). Sustainability indices analysis of farms at landscape scale requires long period data set, which explains the temporal scale responses of the agro-ecological functions. Some of the climate induced changes cannot be measured directly in short time scale but long-term data sets allow more accurate vulnerability and/or resilience analysis. Any farm level analysis of impact of climate change require several individual studies focusing on various farming practices to provide evidence for multiple responses of the given farming systems at landscape to regional scale [99] to apply sustainability indices to analyze resilience scenarios. However, several of factor that contribute for resilient farming systems (Table 5) need critical attention and profiling at landscape scale. Further, it calls for identifying the possible confounding socio-economic factors controlling responses due to technological advancement [100]. Developmental research approach of PAR based analysis of sustainability indices at farm level merits attention to alleviate the climate induced changes to agricultural landscapes. Research literature on analysis of sustainability at farm level is increasing; however there is need for synthesis of the data to design a framework for long-term monitoring of the evolving farms. Further, development of appropriate indicators for regional specific impact analysis and compare them across the socio-economic groups is extremely useful. Likewise, accurate projections of regional climate change would improve the response predictions and impacts on agricultural landscapes at micro to landscape scale.

Table 4. Considerations of significance in effective sustenance of agro-ecological services of farm to landscape scale.

Relevance of approach

Sustenance of functional elements

Identification of sustainable livelihood enhancement with incentive based land use policies for the restoration of ecosystem services

Identification of governing factors for sustainable development

Risk proofing in situation of climate change related hardship in meeting the livelihood
Certain considerations

- Manage sustainably to contribute for wider ecosystem functions such as erosion control, water quality, soil moisture retention, reduced runoff, carbon sequestration, pollination, dispersal of seeds of wild and endangered plants, preserve fragmented refugia of agro-biodiversity.

- Overall landscape biodiversity and genetics enrichment of fauna and flora.

- Range of population needed by agriculture such as pollinators and beneficial predators.

- Adaptation and incentive for the conservation of a diverse range of genetic resources both in situ and ex situ.

- Determining the effect of carbon credit trading in situation of silvi-pastoral, social and farm forestry at individual and community owned forestry as it relates to harvest levels, silvicultural practices and afforestation of agricultural lands.

- $\quad$ Suggest how these land use systems will behave under risk and uncertainty.

- Managing forest for carbon budget may result in modifications to the way agro-forests are managed depending on the incentives provided by carbon markets.

- Implications for policy discussions regarding carbon management and different mechanisms that seek to encourage carbon sequestration.

- Develop strategic plans for evolving a framework for incentive based agro-diversity conservation.

- Physical, biological and meteorological conditions, which is useful in judging the site potential for adapting the management and rehabilitation strategies.

- Site potential to determine the economics of the restoration effort.

- Re-vegetation has to be site specific attempt to improve and/or alter the current vegetation composition and deflect its trajectory towards a more desirable state.

- Critical to have comprehensive knowledge of the responses of target and/or potentially impacted species.

- Demands understanding of ecological principles governing biotic-biotic and biotic-abiotic interaction.

- Monitoring the interaction of environmental factors, biological responsiveness and ecological interaction of species.

- Providing with tools and information for adapting practices to changing climate regimes to improve resilience of farms and stakeholder capacities to reduce risk or make optimal use of climate variability.

- Chronological sequence of agro-meteorological data and tools for assessing the anomalies of weather will aid in guiding adaptation, improving management advice on the basis of current weather monitoring.

- Vulnerability assessment tools.

- Guidance on rural livelihood development related to decision making.

- Promote integrated approaches and synergies between climate change adaptation and disaster risk reduction practices and mechanisms.

- Policy advice to strengthen institutional approaches to adaptation to climate change from a sectoral perspective.

- Thus, promoting sustainability of agro-ecology on the basis of adaptation to climate variability and change; improving farm/household-level food security to help rural populations achieve greater resilience under short-term and medium-term climate variations. 
Table 5. Matrix of factors contributing for resilient farming systems.

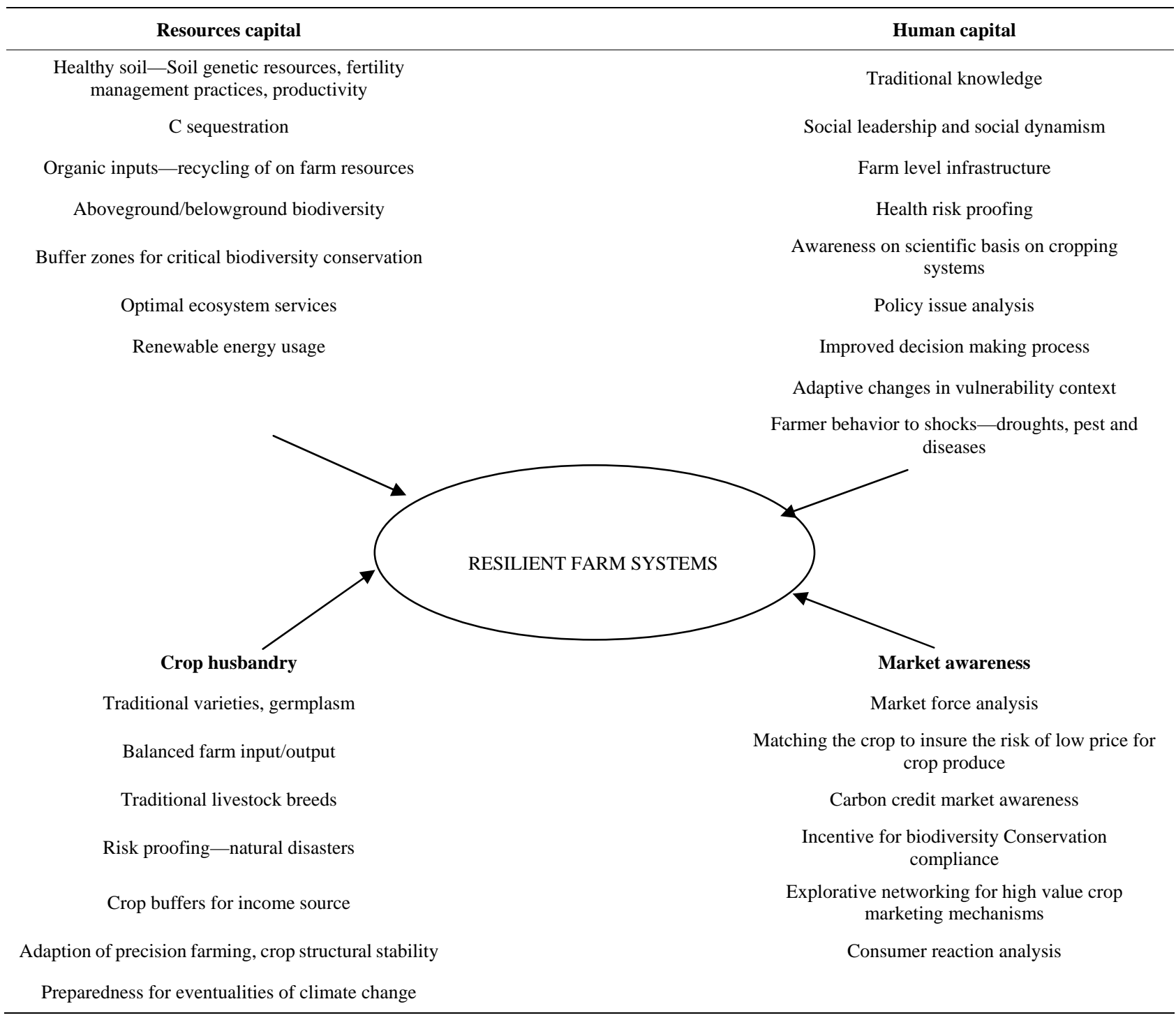

\section{CONCLUSIONS}

Agricultural landscape has prime role in controlling the ecological functions as major ecosystems are fragmented and/or converted to allied land-use systems. Ecological services provided by the pristine ecosystems may assume declining trend due to anthropogenic disturbances and loss of biodiversity. Moreover, given the situation of increase in global population at 8.5 to 10 billion in the next 5 years [101], which means it will be last episode of rapid agricultural expansion. During the period, intensive agricultural activities may irreversibly impact environment and services. Thus, sustainability indicator analysis from farm to landscape scale becomes relevant in designing framework for maintaining the ecological elements. The second green revolution in terms of ecological sustainability and economic viability can be achieved in eco-friendly farming, which imaginatively uses scientific and farm level knowledge base to mix and match conservation agriculture practice with precision approach. PAR provides an apt alternative to analyze the timescale changes in the agricultural practices contributing for the beneficial services and less degradative in nature. In absence of generic diagnostic tools and extension services, sustainability indices based management need to be targeted to smaller farms. Such an approach will benefit the farmers with differing capital asset to contribute for ecological sustenance and diffusing knowledge effectively throughout the community. Improvimng the social capital at farm level will have far reaching implications for building resilient farmlands to climate change adversities and risk proofing the rural economic growth.

Sustainability of agricultural landscapes can be ad- 
dressed at several levels through farming community friendly policy instruments, which encourage diversity in farming systems, removal of subsidies on select degradative farm inputs (input-output levies), identify time tested agricultural models by critical analysis of socio-economic characteristics at landscape scale, which can be adapted with certain modification to suite the current farming systems, design self operational and multiple level network systems for ingenuity sharing among the farming community and design landscape specific information and education program for farming community. Some of these points may be reviewed while debating on policy level reforms by the government and agencies alike to build resilient farming systems. The acceptability and conflict resolving issues of any policy reforms have been difficult to address. However, farm scale approach through PAR will yield positive changes in resolving conflict scenarios which is possibly achieved by the government agencies through designing an incentive based socially acceptable polices, However, policy reforms must consider landscape/region specific issues as it is impossible to design an ideal economic instrument rather define performance-based instruments. The policy reforms by the government agencies thus must consider designing strategies for participatory approaches and co-interest incentive schemes at farm scale to alleviate the sustainability issues of agricultural landscapes.

\section{ACKNOWLEDGEMENTS}

I thank the farmers for the origin of thought to write up the review who had unassuming arguments and shared intuitive wisdom on eroding time tested farming practices. I also thank anonymous reviewer/s for the constructive comments on the manuscript.

\section{REFERENCES}

[1] Rigby, D., Woodhouse, P. Young, T. and Burton, M. (2001) Constructing a farm level indicator of sustainable agricultural practice. Ecological Economics, 39, 463-478. doi:10.1016/S0921-8009(01)00245-2

[2] OECD. (1999) Environmental indicators for agriculture: Concepts and framework. Organisation for Economic Cooperation and Development, Paris.

[3] Gomez, A.A., Kelly, D.E., Syers, J.K. and Coughlan, K.J. (1996) Measuring sustainability of agricultural systems at the farm level. Methods for assessing soil quality. Soil Science Society America Journal, 49, 401-409.

[4] Dalsgaad, J.P.T. and Oficial, R.T. (1997) A quantitative approach for assessing the productive performance and ecological contributions of smallholder farms. Agricultural Systems, 55, 503-533. doi:10.1016/S0308-521X(97)00022-X

[5] Smyth, A.J. and Dumanski, G. (1995) A framework for evaluating sustainable land management. Canadian Jour- nal of Soil Science, 75, 40-406. doi:10.4141/cjss95-059

[6] Boserup, E. (1965) The conditions of agricultural growth: The economics of agararian change under population pressure. Aldine, Chicago.

[7] Thornton, P.K., Galvin, K.A. and Boone, R.B. (2003) An agro-pastoral household model for scenario analysis and impact assessment. Agricultural Systems, 76, 581-602.

[8] Tilman, D., Fargione, J., Wolff, B., D’Antonio, C., Dobson, A., Howarth, R., Schindler, D., Schlesinger, W.H., Simberloff, D. and Swachhamer, D. (2001) Forecasting agriculturally driven global environmental change. Science, 292, 281-284. doi:10.1126/science.1057544

[9] Chapin. F.S., Zavaleta, E.S., Eviners, V.T., Naylor, R.L., Vitousek, P.M., Reynolds, H., Hooper, D.U., Lavorel, S., Sala, O.E., Hobbie, S.E., Mack, M.C. and Diaz, S. (2000) Consequences of changing biodiversity. Nature, 405, 234242. doi:10.1038/35012241

[10] Hails, R.S. (2002) Assessing the risks associated with new agricultural practices. Nature, 418, 685-688. doi:10.1038/nature01016

[11] Glasbergen, P. (2000) The environmental cooperative: Self governance in the sustainable rural development. Journal of Environmental Development, 9, 240-259. doi: $10.1177 / 107049650000900303$

[12] De Jager, A., Onduru, D., van Wijk, M.S., Vlaming, J. and Gachini, G.N. (2001) Assessing sustainability of lowexternal input farm management systems with the nutrient monitoring approach: A case study in Kenya. Agriculture Systems, 69, 99-118. doi:10.1016/S0308-521X(01)00020-8

[13] Baltenweck, I., Staal., S., Ibrahim, M.N.M., Herrero, M., Holmann, F., Jabbar, M., Manyong, V., Patil, B.R., Thornton, P.K., Williams, T., Waithaka, M. and de Wolf, T. (2003) Crop-livestock intensification and interaction across three continents. Main Report. CGIAR System Wide Livestock Program, ILRI, Addis Ababa, 124.

[14] Nicholson, C.F., Thornton, P.K. and Muniga, R. (2004) Household level impacts of dairy cow ownership in coastal Kenya. Journal of Agricultural Economics, 55, 175195. doi:10.1111/j.1477-9552.2004.tb00092.x

[15] Kristjanson, P., Krishna, A., Radeny, M. and Nondo, W. (2004) Pathways out of poverty in eastern Kenya and the role of livestock. PPLPI Working Paper 14, FAO Animal Production and Health Division, Rome.

[16] Sayer, J.A. and Campbell, B.M. (2001). Research to integrate productivity enhancement, environmental protection and human development. Conservation Ecology, 5, 3243.

[17] Pimm, S.I., Russell, G.J., Gittelman, J.L. and Brooks, T.M. (1995) The future of biodiversity. Science, 269, 347. doi:10.1126/science.269.5222.347

[18] Salvatore Di Falco, S.D., Penov, I. Aleksiev, A. and van Rensburg, T.M. (2010) Agrobiodiversity, farm profits and land fragmentation: Evidence from Bulgaria. Land Use Policy, 27, 763-771. doi:10.1016/j.landusepol.2009.10.007

[19] Bishop, J., Kapila, S., Hicks, F., Mitchell, P. and Vorhies, P. (2008) Building biodiversity business. Shell Interna- 
tional Limited and International Union for Conservation of Nature, London, 164.

[20] Nowak, M. (2006) Five rules for the evolution of cooperation. Science, 314, 1560-1563. doi:10.1126/science.1133755

[21] Millennium Ecosystem Assessment. (2005) Living beyond our means: Natural assets and human well-being. Island Press, Washington DC.

[22] Butler, S.J., Vickery, J.A. and Norris, K. (2007) Farmland biodiversity and the footprint of agriculture. Science, 315, 381-384. doi:10.1126/science.1136607

[23] Smyth, A.J. and Dumanski, J. (1993) An international framework for evaluating the sustainable land management. FAO World Resource Report 73 and 74, FAO, Rome.

[24] Swete-Kelly, D. (1996) Development and evaluation of sustainable production systems for steeplands-lessons from the South Pacific. In: Sustainable Land Management in the South Pacific. Network Document No 19, IBSRAM, Bangkok.

[25] Babbington, A. (1999) Capitals and capabilities: A framework for analyzing peasant viability, rural livelihoods and poverty. World Development, 27, 2021-2044. doi:10.1016/S0305-750X(99)00104-7

[26] Werf, H.M.G. and Petit, J. (2002) Evaluation of the environmental impact of agriculture at the farm level: A comparison and analysis of 12 indicator based methods. Agriculture Ecosystems Environment, 93, 131-145. doi:10.1016/S0167-8809(01)00354-1

[27] Herrero, M., Estrada, G.E., Thornton, P.K., Quiros, C., Waithaka, M.M., Ruiz, R. and Hoogenboom, G. (2007) IMPACT: Generic household level databases and diagnosis tools for integrated crop-livestock systems analysis. Agricultural Systems, 92, 240-265. doi:10.1016/j.agsy.2006.03.008

[28] Fernendes, L.A. and Woodhouse, P.J. (2008) Family farm sustainability in southern Brazil: An application of agroenvironmental indicators. Ecological Economics, 66, 243257. doi:10.1016/j.ecolecon.2008.01.027

[29] Yunlong, C. and Smith, B. (1994) Sustainability in agriculture: A general review. Agriculture Ecosystems Environment, 49, 99-307. doi:10.1016/0167-8809(94)90059-0

[30] Dumanski, J. and Pieri, C. (1996) Application of the pressure-state-response framework for the land quality indicators (LQI) program. Proceedings of the Workshop OrGanized by the FAO Agriculture and Sustainable Development Departments, Rome, 25-26 January 1996.

[31] Pretty, J.N. (1995) Regenerating agriculture: Policies and practice for sustainability and self reliance. Earthscan Publications Limited, London.

[32] Tilman, D., Cassman, K.G., Matson, P.A., Naylor, R. and Polasky, S. (2002) Agricultural sustainability and intensive production practices. Nature, 418, 671-677. doi:10.1038/nature01014

[33] Hansen, J.W. (1996) Is agricultural sustainability a useful concept? Agricultural Systems, 50, 117-143. $\underline{\text { doi:10.1016/0308-521X(95)00011-S }}$
[34] Biswas, R.M. (1994) Agriculture and environment: A review 1972-1992. Ambio, 23, 192-197.

[35] Conway. G.R. (1985) Agro-ecosystem analysis. Agriculture Administration, 20, 31-55. doi:10.1016/0309-586X(85)90064-0

[36] Edwards, C.A. and Wali, M.K. (1993) The global need for sustainability in agriculture and natural resources. Agriculture Ecosystems Environment, 46, 7-15.

[37] Tisdell, C. (1996) Economic indicators to assess the sustainability of conservation farming projects: An evaluation. Agriculture Ecosystems Environment, 57, 117-131. doi:10.1016/0167-8809(96)01017-1

[38] Ouedraogo, E., Mando, A. and Zombre, N.P. (2001) Use of compost to improve soil properties and crop productivity under low input agricultural system in West Africa. Agriculture Ecosystems Environment, 84, 259-266. doi:10.1016/S0167-8809(00)00246-2

[39] Altieri, M. (1995) Agroecology: The scientific basis of alternative agriculture. West View Press, Boulder.

[40] Conway, G.R. (1990) Agriculture and the environment: Concept and issues. In: Huq, S., Rahman, A. and Conway, G.R. Eds., Environmental Aspects of Agricultural Development in Bangladesh, University Press, Dhaka.

[41] Clemesten, M. and Larr, J. (2000) The contribution of organic agriculture to landscape quality in the Sogn og Fjordane region of Western Norway. Agriculture Ecosystems Environment, 77, 125-141. doi:10.1016/S0167-8809(99)00098-5

[42] Heller, N.E. and Zavaleta, E.S. (2009) Biodiversity management in the face of climate change: A review of 22 years of recommendations. Biological Conservation, 142, 14-32. doi:10.1016/j.biocon.2008.10.006

[43] Stobbelaar, D.J., Kuiper, J., van Mansvelt, J.D. and Kabourakis, E. (2000) Landscape quality on organic farms in the landscape. Agriculture Ecosystems Environment, 77, 79-93. doi:10.1016/S0167-8809(99)00094-8

[44] Edwards, C.A., Grove, T., Harwood, R.R. and Colfer, J. (1993) The role of agroecology and integrated farming systems in sustainable agriculture. Agriculture Ecosystems Environment, 46, 99-121. doi:10.1016/0167-8809(93)90017-J

[45] Rigby, D. and Caceres, D. (2001) Organic farming and the sustainable agricultural systems. Agricultural Systems, 68, 21-40. doi:10.1016/S0308-521X(00)00060-3

[46] Webster, P. (1999) The challenge of sustainability at the farm level: Presidential address. Journal Agricultural Economics, 50, 371-387. doi:10.1111/j.1477-9552.1999.tb00888.x

[47] Pretty, J.N. and Hine, R. (2000) The promising spread of sustainable agriculture in Asia. National Research Forum, 24, 107-121. doi:10.1111/j.1477-8947.2000.tb00936.x

[48] Ikerd, J.E. (1993) The need for a systems approach to sustainable agriculture. Agriculture Ecosystems Environment, 46, 147-160. doi:10.1016/0167-8809(93)90020-P

[49] Webster, J.P.G. (1997) Assessing the economic consequences of sustainability in agriculture. Agriculture Ecosystems Environment, 64, 95-102. 
doi:10.1016/S0167-8809(97)00027-3

[50] Lynam, J.K. and Herdt, R.W. (1989) Sense and sustainability: Sustainability as an objective in international agricultural research. Agricultural Economics, 3, 381-398. doi:10.1016/0169-5150(89)90010-8

[51] Tellarini, V. and Caporali, F. (2000) An input/output methodology to evaluate farms as sustainable agro-ecosystems: An application of indicators to farms in central Italy. Agriculture Ecosystems Environment, 77, 111-123. doi:10.1016/S0167-8809(99)00097-3

[52] Gowda, M.J.C. and Jayaramaiah, K.M. (1998) Comparative evaluation of rice production systems for sustainability. Agriculture Ecosystem Environment, 69, 1-9. doi:10.1016/S0167-8809(98)00089-9

[53] Reijntjes, C., Bertus, H. and Water-Bayer, A. (1992) Farming the future: An introduction to low external input and sustainable agriculture. Macmillan, London.

[54] Fukuoka, M. (1985) The natural way of farming. Japan Publications, Tokyo.

[55] Iraizoz, B., Gorton, M.S. and Davidova, S. (2007) Segmenting farms for analyzing agricultural trajectories: A case study of the Navarra region in Spain. Agricultural Systems, 93, 143-169. doi:10.1016/j.agsy.2006.05.002

[56] Pimentel, D.C. and Kounang, N. (1998) Ecology of soil erosion in ecosystems. Ecosystems, 1, 104-123. doi:10.1007/s100219900035

[57] Lewis, W.J., van Lenteren, J.C., Pathak, S.C. and Tumlinson, J.H. (1997) A total system approach to sustainable pest management. Proceedings of National Academy of Sciences, 94, 12243-12248.

doi:10.1073/pnas.94.23.12243

[58] Katterer, T. and Andren, O. (1999) Long-term agricultural field experiments in northern Europe: Analysis of the influence of management on soil carbon stocks using the ICBM model. Agricultural Ecosystems Environment, 72, 165-179. doi:10.1016/S0167-8809(98)00177-7

[59] Reed, M., Fraser, E. and Dougill, A. (2006) An adaptive learning process for developing and applying sustainability indicators with local communities. Ecological Economics, 59, 406-418. doi:10.1016/j.ecolecon.2005.11.008

[60] Mitchell, G., May, A. and McDonald, A. (1995) PICABEU: A methodological framework for the development of indicators of sustainable development. International Journal of Sustainable Development, 2, 104-123.

[61] Martinez-Alier, J. (2002) The environmentalism of the poor: A study of ecological conflicts and valuation. Edward Elgar, Cheltenham.

[62] Glenn, N.A. and Pannell, D.J. (1998) The economics and application of sustainability indicators in agriculture. In: Australian Agricultural and Resources Economics Society, University of New England, Armidale, 19-21.

[63] King, C., Gunton, J., Freebarin, D., Coutts, J. and Webb, I. (2000) The sustainability indicator industry: Where to from here? A focus group study to explore the potential of farmer participation in the development of indicators. Australian Journal of Experimental Agriculture, 40, 631642. doi:10.1071/EA99148
[64] French J. (2009) Sustainability in the global perspective: Policy directions for a resilient and conservation-based agriculture. In: Franzluebbers A.J., Ed., Farming with Grass: Achieving Sustainable Mixed Agricultural Landscapes, Soil and Water Conservation Society, Ankeny, 205-215.

[65] Hezri, A. and Dovers, S. (2006) Sustaianability indicators, policy and governance: Issues for ecological economics. Ecological Economics, 60, 86-99. doi:10.1016/j.ecolecon.2005.11.019

[66] SOPAC. (2005) Building resilience in SIDS. The Environmental Vulnerability Index (EVI), Technical Report, South Pacific Applied Geoscience Commission, Suva.

[67] Prescott-Allen, R. (2001) The well-being nations. Island Press, Washington DC.

[68] Hartwick, J.M. (1977) Intergenerational equity and the investing of rents from exhaustible resources. American Economics Review, 67, 972-974.

[69] McNeely, J. (1988) Economics and biological diversity: Developing and issuing economic incentives to conserve biological resources. IUCN, Gland.

[70] UNEP. (2000) Integrated environmental and economic accounting-An operational manual, Oxford University Press, Oxford.

[71] Hanley, N. (2000) Macroeconomic measures and sustainability. Journal of Economics Survey, 14, 1-30. doi:10.1111/1467-6419.00102

[72] Dale, V.H. and Beyeler, S.C. (2001) Challenges in the development and use of ecological indicators. Ecological Indicators, 262, 201-204.

[73] Izac, A.M.N. and Swift, M.J. (1994) On agricultural sustainability and its measurement in small-scale farming in sub-saharan agriculture. Ecological Economics, 11, 105125. doi:10.1016/0921-8009(94)90022-1

[74] Levitan, L., Merwin, I. and Kovach, J. (1995) Assessing the relative environmental impacts of agricultural pesticides: The quest for a holistic approach. Agriculture Ecosystem Environment, 55, 153-168. doi:10.1016/0167-8809(95)00622-Y

[75] Guijt, W.J. (1996) Policies that work for sustainable agriculture and regenerating rural economies: Some methodological considerations. Sustainable Agriculture Program, IIED, London.

[76] Meul, M., Nevens, F. and Reheul, D. (2009) Validating sustainability indicators: Focus on ecological aspects of Flemish dairy farms. Ecological Indicators, 9, 284-295. doi:10.1016/j.ecolind.2008.05.007

[77] Scoones, I. (1999) The new ecology and the social sciences: What prospects for a fruitful engagement? Annual Review of Anthropology, 28, 479-507. doi:10.1146/annurev.anthro.28.1.479

[78] Tilman, D. (1998) The greening of the green revolution. Nature, 396, 211-212. doi:10.1038/24254

[79] Gliessman, S. (2009) Community-based participatory action research with agroecology. Journal Sustainable Agriculture, 33, 799-800.

[80] Stringer, E.T. (1999) Action research: A handbook for practitioners. Sage Publications, Thousand Oaks. 
[81] Mooghali, A.R. and Azizi, A.R. (2008) Relation between organizational intelligence and organizational knowledge management development. World Journal of Applied Science, 4, 1-8.

[82] Walters, C.J. and Hilborn, R. (1978) Ecological optimization and adaptive management. Annual Review Ecological Systems, 9, 157-188.

doi:10.1146/annurev.es.09.110178.001105

[83] Shea, K., Possingham, H.P. Murdoch, W.W. and Roush, R. (2002) Active adaptive management in insect pest and weed control: Intervention with a plan for learning. Ecological Applications, 12, 927-936. doi:10.1890/1051-0761(2002)012[0927:AAMIIP]2.0.CO; $\underline{2}$

[84] Biggs, S.D. (1989) Resource-poor farmer participation in research: A synthesis of experiences from nine national agricultural research systems. OFCOR - Comparative Study, INSAT, Hague.

[85] McCarthy, M. and Possingham, H.P. (2007) Active adaptive management for conservation. Conservation Biology, 21, 956-963. doi:10.1111/j.1523-1739.2007.00677.x

[86] Cooke, B. and Kothari, U. (2001) Participation: The new tyranny? Zed Books, London.

[87] Huges, D.E. (1995) Environmental sociology: A distinct field of inquiry? In: Mehta, M.D. and Ouelett, E., Eds., Environmental Socialogy: Theory and Practice, Captus Press Inc., Ontario.

[88] Bourdeu, P. (2004) The man-nature relationship and environmental ethics. Journal of Environmental Remediation, 72, 9-15.

[89] Roling, N. (2003) From causes to reasons: The human dimension of agricultural sustainability. International Journal of Agricultural Sustainability, 1, 73-88.

[90] Rezaei, M., Karami, K. and Gibson, J. (2005) Conceptualizing sustainable agriculture: Iran as an illustrative case. Journal of Sustainable Agriculture, 27, 25-56. doi:10.1300/J064v27n03_04

[91] Daniels, S.E. and Walker, G.B. (1996) Collaborative learning: Improving public deliberation in ecosystem-based management. Environmental Impact Assessment Review, 16, 71-102. doi:10.1016/0195-9255(96)00003-0
[92] Sala, O.E., Chapin, F.S., Armesto, J.J., Berlow, E., Bollmfield, J., Dirzo, R., Huber-Sanwald, E., Huenneke, L.F., Jackson, R.B., Kinzig, A., Leemans, R., Lodge, D.M., Mooney, H.A., Oesterheld, M., Poff, N.L., Sykes, M.T., Walker, B.H., Walker, M. and Wall, D.H. (2000) Global biodiversity scenarios for the year 2100. Science, 287, 1770-1774. doi:10.1126/science.287.5459.1770

[93] Channell, R. and Lomolino, M.V. (2000) Dynamic biogeography and conservation of endangered species. $\mathrm{Na}$ ture, 403, 84-86. doi:10.1038/47487

[94] Schlesinger, W.H., Reynolds, J.F., Cunningham, J.L., Huenneke, L.F., Jarrell, W.M., Virginia, R.A. and Whitford, W.G. (1990) Biological feedbacks in global desertification. Science, 247, 1043-1048. doi:10.1126/science.247.4946.1043

[95] Reilly, J.M. and Schimmelpfenning, D. (1999) Agricultural impact assessment, vulnerability, and the scope for adaptation. Climate Change, 43, 745-788. doi:10.1023/A:1005553518621

[96] Rothman, D.S. (2000) Measuring environmental values and environmental impacts: Going from the local to the global. Climate Change, 44, 351-376. doi:10.1023/A:1005645301478

[97] Darwin, R. (1999) A farmer's view of the Ricardian approach to measuring agricultural effects of climatic change. Climate Change, 41, 371-411. doi:10.1023/A:1005421707801

[98] FAO. (1998) The State of the World's plant genetic resources for food and agriculture. Food and Agriculture Organization of the United Nations, Rome.

[99] Mendelsohn, R. and Dinar, A. (1999) Climate change, agriculture and developing countries: Does adaptation matter? World Bank Reserve Observatory, 14, 277-293.

[100] Leemans, R. (1997) Effects of global change on agricultural land use: Scaling up from physiological processes to ecosystem dynamics. In: Jackson, L.E., Ed., Ecology in Agriculture, Academic Press, San Diego, 415-452. doi:10.1016/B978-012378260-1/50013-0

[101] Cohen, J.E. (1995) How many people can the earth support? Norton, New York. 